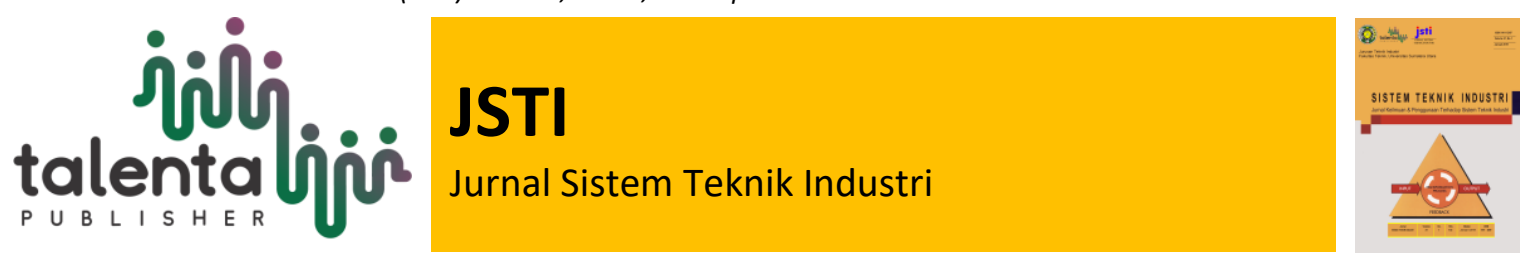

\title{
Effect of Wearing Different Types of Face Mask to Heat Strain During Physical Activities
}

\author{
Danarwan Rusdaniajï ${ }^{1}$, Rini Dharmastiti ${ }^{2}$ \\ ${ }^{1,2}$ Laboratorium Ergonomi, Department of Mechanical and Industrial Engineering,, Universitas Gadjah \\ Mada, Yogyakarta, Indonesia 55281
}

\begin{abstract}
There is a concern to use masks during physical activities when exercising and working. Wearing masks during physical activity will pose a risk to physiological changes in the body and human heat strain by the principle of a mask can block the respiratory tract. This study aims to determine how much the human physiological changes quantitatively and qualitatively when using different types of medical masks, cloths and N95. There were 10 respondents as a sample of this study. The results obtained show that the different types of masks to the physiological response of the human body, cloth masks can affect the physiological changes the highest compared to medical masks and N95. The subjective response in the form of thermal comfort, mask sensation, and thermal sensation shows that of the 3 types of masks, the N95 mask is the mask that is the most uncomfortable when worn. The recommendations of the 3 types of masks are medical masks because they affect the slightest increase in the risk of heat stress while the cloth masks have the highest increase in tympanic temperature and Physiological Strain Index.
\end{abstract}

Keyword: Heat Strain, Mask, Physical Activities

\begin{abstract}
Abstrak. Terdapat kekhawatiran di sebagian masyarakat untuk menggunakan masker saat beraktivitas fisik seperti pada saat berolahraga dan bekerja. Penggunaan masker pada saat beraktivitas fisik dikhawatirkan akan memiliki risiko terhadap perubahan fisiologis tubuh dan heat strain manusia karena cara kerja masker yang menutup saluran pernapasan. Penelitian ini bertujuan untuk mengetahui seberapa besar perubahan fisiologis manusia secara kuantitatif dan kualitatif pada saat menggunakan jenis masker yang berbeda yaitu masker medis, kain dan N95. Terdapat 10 responden sebagai sampel dari penelitian ini. Hasil penelitian yang diperoleh menunjukan bahwa perbedaan jenis masker berpengaruh terhadap respon fisiologis tubuh. Masker kain dapat mempengaruhi perubahan fisiologis yang paling tinggi dibandingkan masker medis dan N95. Pada respon subjektif berupa thermal comfort, mask sensation, dan thermal sensation menunjukan bahwa dari ke 3 jenis masker tersebut masker N95 merupakan masker yang paling dirasa tidak nyaman saat dipakai. Rekomendasi dari ke 3 jenis masker tersebut ialah masker medis karena mempunyai pengaruh terhadap kenaikan risiko heat stress yang paling ringan sedangkan untuk masker kain mempunyai pengaruh terhadap kenaikan temperatur timpani dan PSI yang paling tinggi.
\end{abstract}

Kata Kunci: Aktivitas Fisik, Heat Strain, Masker

Received 04 June 2021 | Revised 30 June 2021 | Accepted 15 July 2021

\footnotetext{
*Corresponding author at: Department of Mechanical and Industrial Engineering, Faculty of Engineering, Universitas Gadjah Mada, Jln. Grafika No. 2, Kampus UGM, Yogyakarta, 55281, Indonesia 


\section{Introduction}

There are several health issues regarding the use of masks during physical activity. Previous study suggested that the N95 mask causes discomfort breathing with an average reduction of $37 \%$ in air exchange volume [1]. Wearing the N95 mask can increase the fatigue of medical rescue workers and decrease the quality of chest compressions during the cardiopulmonary resuscitation process (CPR) [2]. The use of masks in soccer athletes can cause respiratory problems and other complications such as hypoxia and hypercapnic as evidenced by the increased physical load during physical activity [3]. Apart from these health risks, there are other health risks. The risk is about thermal hazards or heat stress on the human body. Wearing a cloth mask can reduce exercise performance, VO2 peak and heart rate variables in respondents when doing physical activities running on a treadmill [4]. Physiological strain index (PSI) based on tympanic temperature (Tty) and heart rate (HR) being able to show heat strain accurately and analyze in the human body to assess the Physiological Strain Index (PSI) on a universal scale of 0-10 [5].

One of the factors for thermal comfort and high risk of heat stress is heat strain. Heat strain is defined as a physiological response to thermal stress involved in maintaining the body's thermal balance [6]. Thermal comfort for humans with higher activity requires further consideration, the results of research conducted noted that the air temperature and sweat levels required for comfort will depend on the level of physical activity carried out [7]. The use of masks in the long term when doing physical activity will affect a person's body condition from physiological factors such as body temperature, heart rate, blood pressure, and others [8]. Numerous studies have demonstrated that health care workers are, in general, poorly compliant with respiratory protection guidelines, especially when a N95 respirator is recommended [9]. More recently, a direct comparison of N95s to surgical masks found that surgical masks were not inferior to N95 respirators at protecting while working [10]. This can be a concern if there are many effects caused by using an inappropriate mask during physical activities. The selection of the right type of mask will also affect the comfort and safety of a person when using it.

In this study, the effect of using a mask during physical activity on the risk of heat stress in the human body will be investigated. In addition, this study will compare the types of masks that have the least risk of heat stress on the human body and its effect on body thermoregulation during physical activity. The result from this study will provide about the physiological condition of a person who uses a different type of mask during physical activity from the risk of heat stress.

The purpose of this study was to analyze and compare thermal physiological changes in the human body. The variable is skin temperature (Tsk), tympanic temperature (Tty), heart rate (HR), and oxygen levels ( $\mathrm{SpO} 2)$ from the wearing of three different types of masks during physical activities. The next aim of this research is to know in a subjective way by using a thermal sensation, thermal comfort, and mask sensation to respondents by wearing different types of masks and recommending the best type of mask from 3 different types of materials (medic, cloth, N95) during physical activities against the risk of heat stress on the human body. based on the level of Physiological Strain Index (PSI) obtained. 


\section{Related Work}

Previous researched has stated that the use of masks can trigger an increase in the temperature of the microclimate inside the mask and make limited the flow of heat that comes out through the respiratory system, it can result in a significant accumulation of the heat metabolic system in the human body if the microclimate temperature is high above the normal human body temperature [11]. Stated that breathing apparatus by masks can inhibit the heat generated from the respiratory process and accumulate in the mask when used the temperature develops into a new climate called microclimate and the humidity is very different from the air in the outside environment [12].

Johnson's [13] has researched about wearing a mask while doing physical activity there are 6-10 minutes of normal activity that can occur before the body temperature increases significantly. Skin temperature will increase if sufficient heat disable lost to the environment, then body temperature will continue to increase until it reaches a dangerous level [14]. Previous research regarding thermal sensation states that environmental factors that affect subjective perception are usually divided into three categories, namely physical, physiological, and psychological factors.

Most previous experiments in climate chambers were designed to test subjects' physiological responses under various parameters of the physical environment. The findings of an experiment when exercising demonstrated that strenuous aerobic exercise measured during maximal standards when using an N95 respirator revealed a mild but significant increase in carbon dioxide $(\mathrm{CO} 2)$ levels at partial pressures that were more pronounced when the exercise level was increased and with an N95 respirator [15].

Kim, et al. in [16] has found that the use of Full Filtering Respiratory (FFR) N95 and N95 FFR / $\mathrm{EV}$ with a workload of more than 1 hour had a limited impact on $\mathrm{SpO} 2$, breathing rate (fB), and heart rate in young and healthy individuals.

\section{Methodology}

\subsection{Study Design and Participants}

This study is an experimental method carried out in a conditioned room inside the Ergonomics Laboratory of the Department of Mechanical and Industrial Engineering, Gadjah Mada University in April 2021 with a room temperature of $31^{\circ} \mathrm{C}$ and a humidity of $84 \% \mathrm{RH}$. Research respondents will carry out physical activity in the form of brisk walking on a treadmill with 3 conditions, there are the condition by wearing a medical mask, the condition by wearing a cloth mask and the condition by wearing an N95 mask. The clothes used by the respondents during the study were short-sleeved shirts and cotton shorts with a clo value of 0.16 . All respondents in this study were male and in good health and with a BMI value $<25$ which indicates to ideal body weight. This study uses respondents consisting of 10 men with the criteria as in table 1 . 
Table 1 Respondent Characteristics

\begin{tabular}{llc}
\hline No & Parameter & Value \\
\hline 1 & Age (year) & $22-26$ \\
2 & Weights (Kg) & $60-78$ \\
3 & Height (cm) & $165-180$ \\
4 & Body Mass Index & $<25$ \\
5 & Hrmax (bpm) & $196 \pm 3,1$ \\
\hline
\end{tabular}

\subsection{Instrument}

Three models of face mask respirators with distinct designs of the facepiece were included. Different types of face mask and respirator is needed to see the effect of mask to the physiological system in the body the face mask is divided three types as we can see in Figure 1.

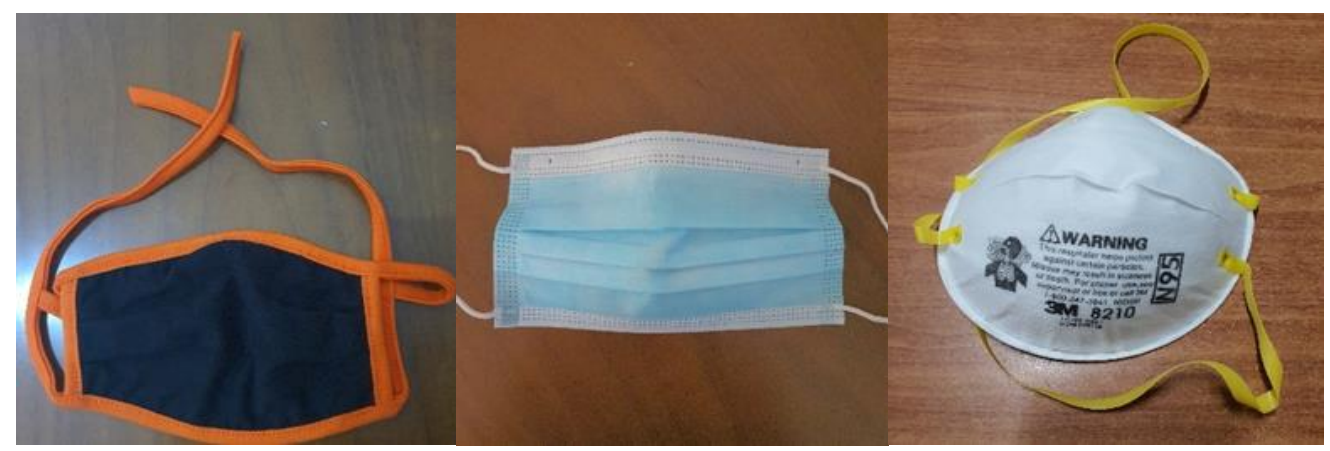

Figure 1 Different Type of Mask (Left to Right) Cloth Mask, Medical Mask, N95 Mask

The first model included a cloth mask is a most popular mask to wear in the outdoor activity, the material of this mask is a cotton with 3 ply standard, This mask can be washed after use. The second model is a medical mask who commonly used by a medical worker in indoor or outdoor field and a doctor when doing a medical operation such as surgery. The last model it has filtered facepiece molded in the shape of a hemispherical cup in which the filter was integrated as an inseparable part of the mask. The masks in this model were frequently referred to as the N95 masks. The filtering facepiece was attached with welded straps, soft nose foam, and an adjustable nose clip for fixation of the mask to the face, this model was commonly used in hospitals and public facilities for protection against exposure to bioaerosols and particulates [17]. Table 2 shows the specifications and designs of these respirators that influence the dissipation of respiratory heat and development of thermal physiologic on human body.

Table 2 Mask Specification

\begin{tabular}{ll}
\hline Mask Type & Specification \\
\hline Medical Mask & Sensi Multi One Plus Earloop 3 Ply Surgical Mask \\
Cloth Mask & Cloth Mask Cotton Material 3ply \\
N95 Mask & 3M respirator valve 9501V /9001V \\
\hline
\end{tabular}




\subsection{Experiment Protocol}

The first step before conducting this experiment is measuring the maximum heart rate. This is intended to determine the speed and workload of the respondents according to their respective abilities. Heart rate (HR) is often used to calculate exercise intensity. One formula that is often used is the Karvonen formula [18]. This formula is often used in the field of physical exercise and medical rehabilitation. The formula for calculating maximum heart rate is:

$$
\text { HRmax }=220-\text { Age }
$$

HRmax measurements were carried out on subjects using the Bruce method to determine the maximum body capacity when doing activities [19]. The results of the HRmax measurement are then used as the basis for determining the workload of the respondents in the fast walking experiment on a treadmill, which is $65 \%$ of HRmax. HRmax was calculated used by equation. Treadmill speed on each subject can be determined from the equation. The next stage is to experiment with experimental design. The experiments following the Design of Experiment (DoE) design. In Table 3.3 are the data variables needed during the research.

Table 3 Research Variables

\begin{tabular}{|c|c|c|}
\hline Methods & Parameter & Value \\
\hline Direct Measurement & Physiological Change & $\begin{array}{l}\text { Face Skin Temperature (Tsk) } \\
\text { Oxygen Level }\left(\mathrm{SpO}_{2}\right)\end{array}$ \\
\hline Quantitative & Heat Strain Index & $\begin{array}{l}\text { Heart Rate (HR) } \\
\text { Tympanic Temperature (Tty) } \\
\text { Physiological Strain Index (PSI) }\end{array}$ \\
\hline Subjective & $\begin{array}{l}\text { Subjective Perception } \\
\text { Scales }\end{array}$ & $\begin{array}{l}\text { Thermal Comfort } \\
\text { Thermal Sensation } \\
\text { Mask Sensation }\end{array}$ \\
\hline
\end{tabular}

Figure 2 show the timeline of this experiment protocol. Following an acclimatization for $15 \mathrm{~min}$ on a chair (R0), the subject voided the bladder completely and put on a facemask, randomly selected. Then, the subject walked for $20 \mathrm{~min}$ (E1). During the exercise stage, every 5 minutes the tympanic temperature, oxygen level, heart rate, and skin temperature around the mouth will be recorded. The next step is to do this experiment. There are 3 phases in each condition, namely the acclimatization phase, exercise phase and resting phase.

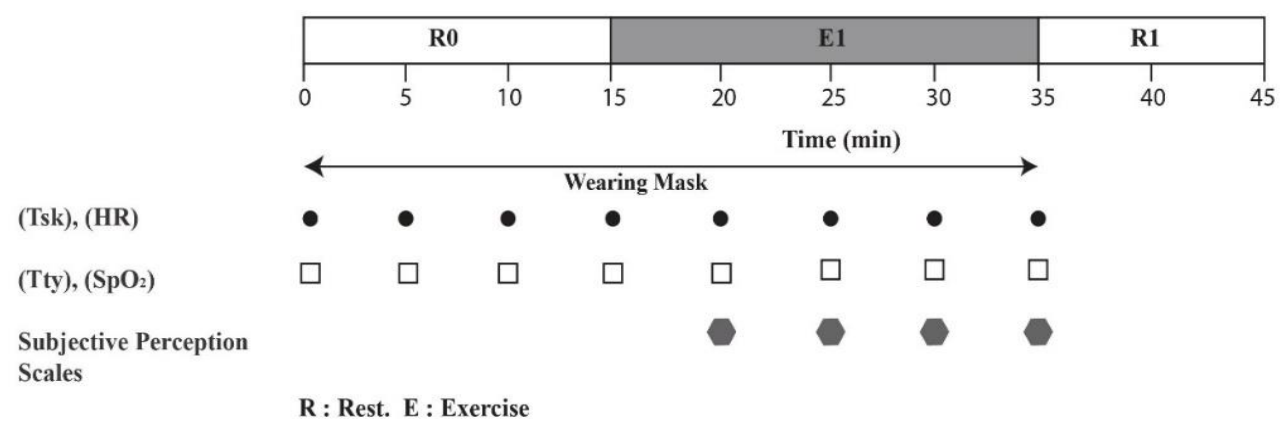

Figure 2 Research Experiment Timeline Protocol 
The experiments were carried out for 1 months from 1 April to 1 May 2021. They were performed in one day, The experimental protocol was randomized for the three types of facemasks. A subject entered the conditioned room controlled at an air temperature of $31^{\circ} \mathrm{C}$ and a relative humidity of $84 \%$ which is similar to the conditions in the outdoor temperature in afternoon at Yogyakarta city. After body mass had been measured, the subject wore a $100 \%$ cotton T-shirt, short pants and running shoes. Thermogun, tympanic thermometer, pulse oxymeter, and heart rate monitor were attached to different areas when exercise begin. Figure 3.3 show that the experiment phase on respondent.

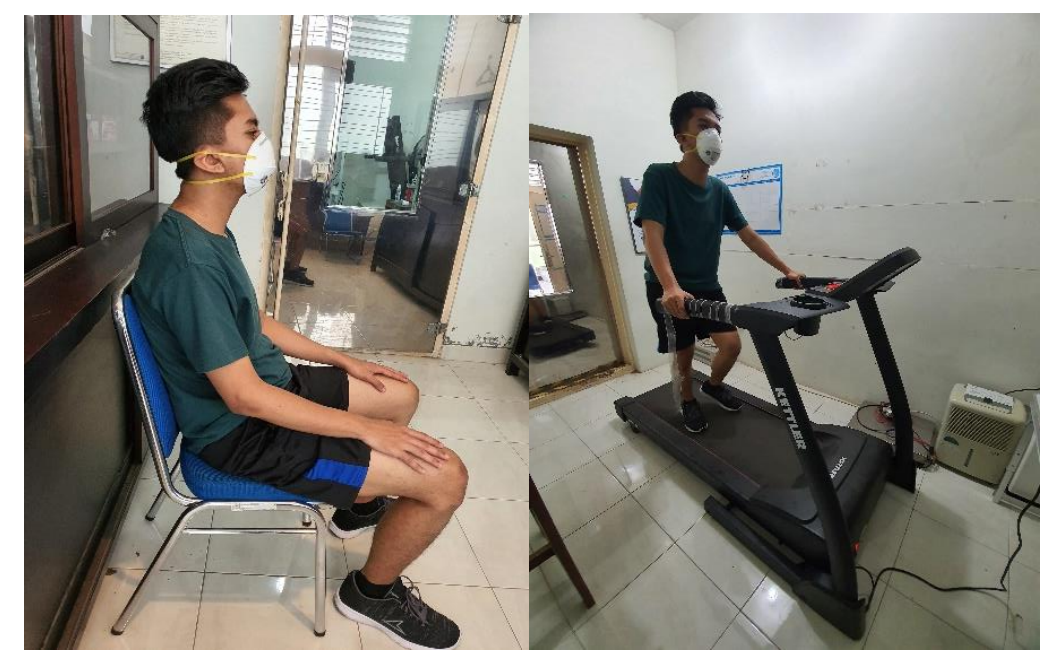

Figure 3 Acclimatization and Exercise Phases (Left to Right) for Respondents When Experiments Take Place in Conditioned Rooms

\subsection{Data Collection}

Data collection in this study was taken by direct measurement and self-report methods. In the direct measurement method used, the data is take directly to the subject to be studied. The data obtained in the form of variables listed as in Table 3.3. This method is carried out in an empirical way to seeing and recording every physiological change that occurs in the subject according to the research variables. Then the results of the data will be tested statistically using the IBM SPSS 20 tool and then using the RM ANOVA test and the Friedman test. The results of the data will then be analyzed and supported by previous research.

Subjective data were collected from the results of questionnaires filled out by respondents during the exercise phase, a questionnaire in the form of Subjective Perception Scales that contained data values for Thermal Sensation, Mask sensation and Thermal Comfort. In the Thermal Sensation Questionnaire, respondents will fill out a questionnaire about the temperature comfort felt by the body during physical activities using a mask, mask sensation is a sensation of comfort when using a mask during physical activity and Thermal Comfort is a sense of comfort at the temperature around the face [20]. All of the subjective data will be used a scale number to represent a feel about a comfortable sensation when using a mask during a physical activity from respondent perspective. 


\section{Result and Discussion}

\subsection{Physiological Measurement Results}

In total, 10 respondents all-male participated in this study. The first experiment is to collect data from physiological measurements. The variable of a physiological data source is from Table 3.3. Data results were summarized every condition of different types of the mask such as medical mask conditions in Table 4. Table 5 showed the cloth mask condition and Table 6 for the N95 mask condition. The data was directly taken from respondents every 5 minutes until the experiment is done. There was 2 phase for the experiment time, the minus number is for acclimatization phase and has 15 minutes while the exercise phase is for 20 minutes long.

Table 4 Experiment Results Medical Mask Condition

\begin{tabular}{llcccc}
\hline $\begin{array}{l}\text { Time } \\
(\mathrm{min})\end{array}$ & $\begin{array}{l}\text { Heart } \\
\text { Rate }\end{array}$ & $\begin{array}{c}\text { Tympanic } \\
\text { Temperature } \\
\left({ }^{\circ} \mathrm{C}\right)\end{array}$ & $\begin{array}{c}\text { Skin Face } \\
\text { Temperature } \\
\left({ }^{\circ} \mathrm{C}\right)\end{array}$ & $\begin{array}{c}\text { Oxygen } \\
\text { Level } \\
(\%)\end{array}$ & $\begin{array}{c}\text { Physiological } \\
\text { Strain Index } \\
(\mathrm{PSI})\end{array}$ \\
\hline-15 & 110,3 & 36,86 & 36,43 & 97,2 & \\
-10 & 103,9 & 36,86 & 36,42 & 97,1 & \\
-5 & 105,3 & 36,82 & 36,5 & 97,4 & \\
0 & 104,2 & 36,85 & 36,51 & 97,3 & 0 \\
5 & 126,4 & 37,16 & 36,46 & 96,9 & 1,882367756 \\
10 & 133,4 & 37,27 & 36,51 & 97 & 2,662247759 \\
15 & 134,9 & 37,23 & 36,47 & 97,3 & 2,652843835 \\
20 & 133,3 & 37,28 & 36,49 & 97,3 & 2,75411489 \\
\hline
\end{tabular}

Table 5 Experiment Results Cloth Mask Condition

\begin{tabular}{llcccc}
\hline $\begin{array}{l}\text { Time } \\
(\mathrm{min})\end{array}$ & $\begin{array}{l}\text { Heart } \\
\text { Rate }\end{array}$ & $\begin{array}{c}\text { Tympanic } \\
\text { Temperature } \\
\left({ }^{\circ} \mathrm{C}\right)\end{array}$ & $\begin{array}{c}\text { Skin Face } \\
\text { Temperature } \\
\left({ }^{\circ} \mathrm{C}\right)\end{array}$ & $\begin{array}{c}\text { Oxygen } \\
\text { Level } \\
(\%)\end{array}$ & $\begin{array}{c}\text { Physiological } \\
\text { Strain Index } \\
(\mathrm{PSI})\end{array}$ \\
\hline-15 & 107,4 & 36,84 & 36,37 & 97,2 & \\
-10 & 101,9 & 36,78 & 36,48 & 97,3 & \\
-5 & 97,3 & 36,85 & 36,49 & 97,5 & \\
0 & 100,3 & 36,89 & 36,52 & 97,3 & 0 \\
5 & 127,2 & 37,24 & 36,54 & 97,2 & 2,293290796 \\
10 & 130,3 & 37,19 & 36,56 & 97,4 & 2,399582902 \\
15 & 137,1 & 37,3 & 36,52 & 97,2 & 3,028590561 \\
20 & 140,6 & 37,32 & 36,53 & 97,2 & 3,324073929 \\
\hline
\end{tabular}

Table 6 Experiment Results N95 Mask Condition

\begin{tabular}{llcccc}
\hline $\begin{array}{l}\text { Time } \\
(\mathrm{min})\end{array}$ & $\begin{array}{l}\text { Heart } \\
\text { Rate }\end{array}$ & $\begin{array}{c}\text { Tympanic } \\
\text { Temperature } \\
\left({ }^{\circ} \mathrm{C}\right)\end{array}$ & $\begin{array}{c}\text { Skin Face } \\
\text { Temperature } \\
\left({ }^{\circ} \mathrm{C}\right)\end{array}$ & $\begin{array}{c}\text { Oxygen } \\
\text { Level } \\
(\%)\end{array}$ & $\begin{array}{c}\text { Physiological } \\
\text { Strain Index } \\
(\mathrm{PSI})\end{array}$ \\
\hline-15 & 109,3 & 36,92 & 36,4 & 96,9 & \\
-10 & 103,4 & 36,96 & 36,38 & 96,9 & \\
-5 & 101,2 & 36,95 & 36,42 & 97 & \\
0 & 101,4 & 36,91 & 36,47 & 97,2 & 0 \\
5 & 128,1 & 37,13 & 36,52 & 97,3 & 2,08999655 \\
10 & 131,9 & 37,17 & 36,52 & 97,1 & 2,39796852 \\
15 & 140,4 & 37,17 & 36,57 & 97,1 & 2,960416785 \\
20 & 136,3 & 37,26 & 36,57 & 97,4 & 2,920842984 \\
\hline
\end{tabular}


The results of the physiological response to facial skin temperature in Figure 4 show that the N95 mask has increased at -10 minutes since, in the acclimatization phase or 10 minutes before the exercise phase, the increase in temperature was also experienced by 2 other masks. The most significant change in temperature and the biggest change during the experiment was cloth masks. Relate to other studies when wearing a cloth mask can reduce exercise performance, VO2 peak, and heart rate variables in respondents when doing physical activities running on a treadmill and doing CPET [21].

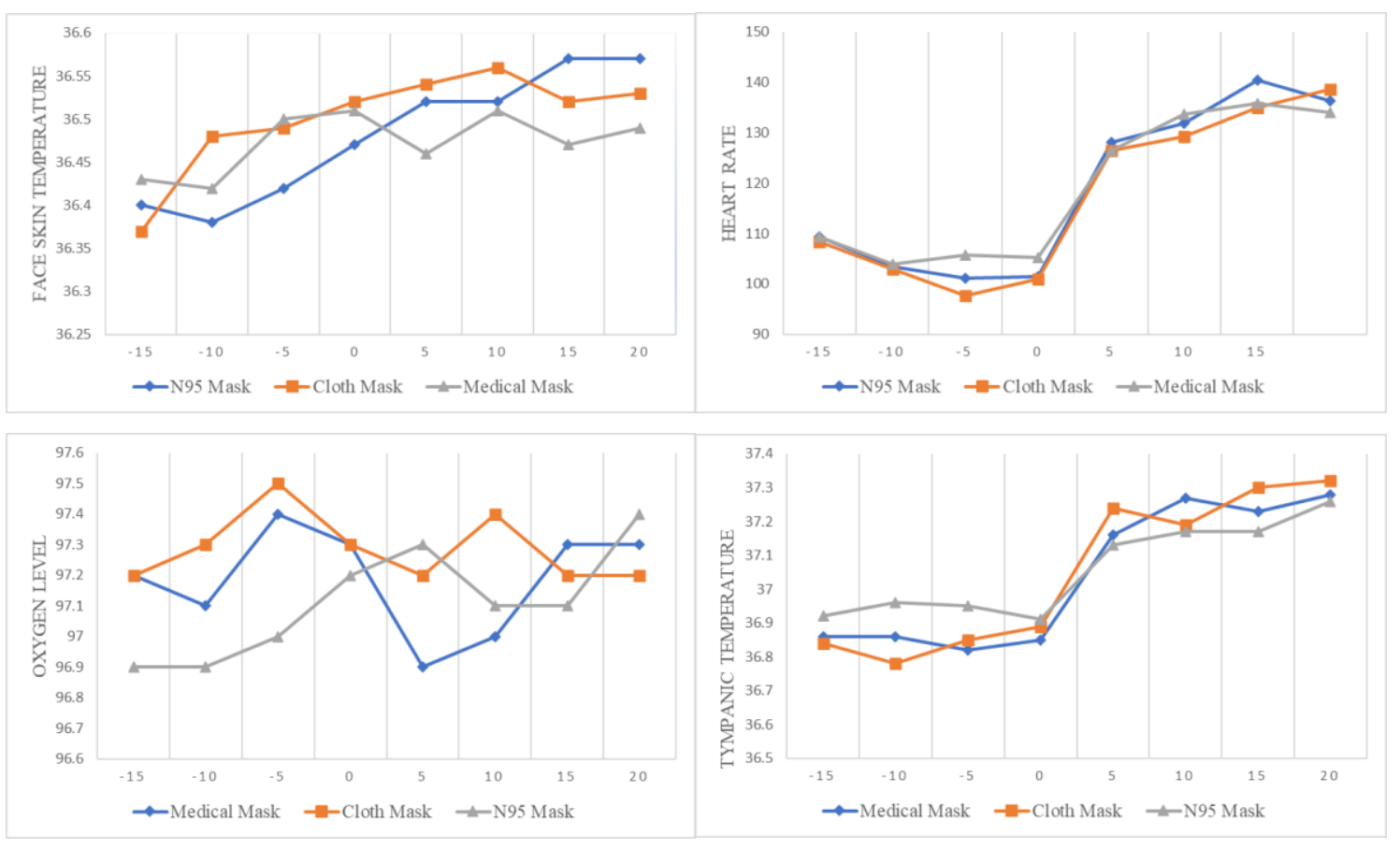

Figure 4 Graphic Data Physiological Result of Face Skin Temperature, Heart Rate, Oxygen Level, Tympanic Temperature

This proves that the temperature of the facial skin when wearing the mask when it is idle or the equalization of facial skin temperature with environment temperature by wearing a N95 mask shows a constant increase. This statement is supported by a previous study which stated that an increase in facial skin temperature was experienced often and always by $56 \%$ of health workers who wore N95 FFR masks while waiting for patients [22].

Different with medical masks, it can be seen that at 5 and 15 minutes the temperature decreases, while in cloth masks, the temperature decreases at 15 minutes. The RM ANOVA test shows a number ( $\mathrm{sig}<0.05$ ) which indicates that $\mathrm{H}_{0}$ is rejected and $\mathrm{H}_{1}$ is accepted, namely $\mathrm{H}_{0}$ exists. the average difference of physiological variables on the type of mask, but there was no significant difference between conditions ( $p>0.05$ ) and the interaction of conditions with time ( $p>0.05)$.

The physiological response to tympanic temperature in Figure 4 shows that cloth masks have the highest increase in tympanic temperature at 5,15 and 20 minutes, then medical masks experience the highest increase in tympanic temperature at 10 minutes, while N95 masks appear to have the lowest tympanic temperature. 2 other mask conditions. In the acclimatization phase, it shows that 
the N95 mask has the highest temperature of the other 2 masks. This shows that N95 masks during physical activity have the lowest body temperature compared to cloth masks.

The condition of wearing a mask during physical activity gives a change in heart rate behavior, it is seen that from the 3 conditions, different types of masks affect changes in heart rate. Cloth masks have the highest change in heart rate at 20 minute but at 5 minutes during the acclimatization phase, cloth masks have the lowest changes in heart rate. Medical masks have the lowest HR changes in the exercise phase. This is in accordance with previous research that surgical masks produce a slight increase in facial skin temperature so that they are more comfortable than the uncomfortable N95 masks based on subjective RPE values of 20 respondents [23].

In the acclimatization phase, N95 masks have the lowest oxygen value in the acclimatization phase, These SpO2 findings are in line with those of other recent studies 18-20 that have examined the impact of various types of negative pressure protective facemasks ( N95 FFR, N95 FFR/EV, elastomeric air-purifying respirators,surgical masks) on $\mathrm{SpO} 2$ and found minimal impact [24] then there is an increase up to 5 minutes and a decrease thereafter, while cloth masks have the highest oxygen levels in the acclimatization phase at -5 minutes and 10 minutes, while medical masks have the highest oxygen levels in the acclimatization phase. Oxygen levels tend to rise and fall with a significant increase in the 10 to 5 minute and while in the exercise phase, there is a decrease in the 0 to 5 minute and thereafter an increase.

\subsection{Subjective Results}

Subjects were required to rate their perceptions of 3 sensations of discomfort by rating on a scale ranging from -4 to 4 , with 0 representing "neutral", 4 representing "very comfort" and -4 representing "very discomfort". This rating was used to obtain the preference of subjects for the three kinds of facemasks. Figure 5 compares subjective ratings for thermal sensation, mask sensation, and overall discomfort for the 3 types of facemasks.
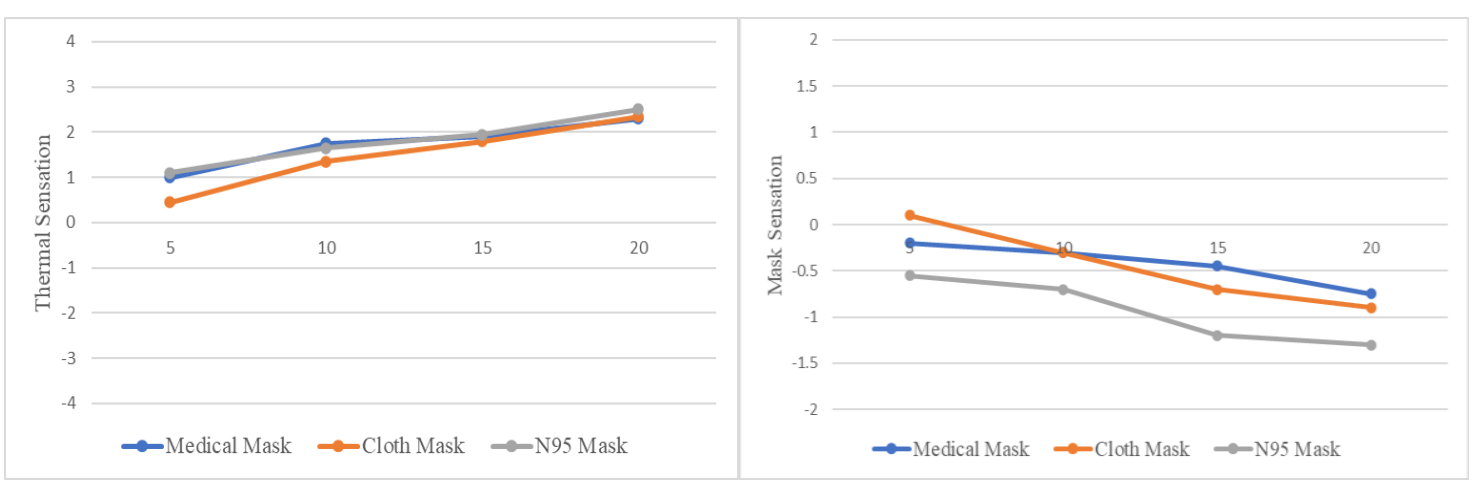

Figure 5 Graphic Data Subjective Result of Thermal Sensation and Mask Sensation

For the 3 types of mask conditions, it appears that the response changes are the same and tend to be stable. During the exercise phase, the condition of the cloth mask looks the most comfortable compared to cloth masks and N95. This shows that the 3 conditions of respondents feel a sensation 
of heat that is not so different. From the result of the subjective test, we know that medical masks have the most comfortable final value, where at minute 20 medical masks have the most comfortable value compared to the other two conditions. This finding is related to previous research, the surface temperature outside the facemask was lower, and the temperature in the facemask microclimate was significantly higher for the N95 masks than for the surgical masks [25]. Meanwhile at the beginning of the exercise phase, cloth masks have the highest comfortable value at minute 5 while N95 masks tend to be constant and has the least comfortable value between the two types of masks.

Figure 6 shows a higher level of comfort in medical and cloth masks compared to N95 masks. This is under the results of the physiological response data, namely Tsk where the N95 mask has the highest temperature compared to the other two conditions.

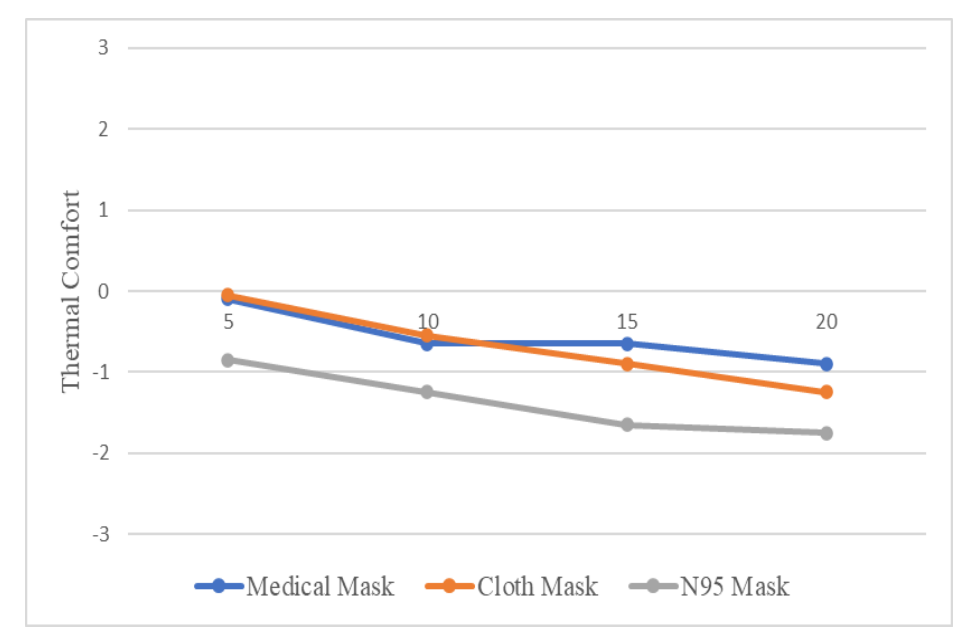

Figure 6 Graphic Data Subjective Result of Thermal Comfort

The result for this experiment of subjective result related to previous research that found the increases in heart rate, skin temperature, and subjective ratings when wearing N95 mask may pose substantial additional stress to the wearer and might reduce work tolerance [26]. This causes discomfort for a respondent to exercise with that mask.

\section{Conclusion and Future Research}

The results from the experiment demonstrate that thermal physiological, heat strain, and subjective ratings were significantly influenced by the wearing of different kinds of facemasks. In the physiological response, cloth masks have the highest physiological changes compared to medical masks and N95. The results of subjective responses show that the N95 mask is the most uncomfortable mask when worn. The other mask especially medical mask have a lightest risk of heat stress while for cloth masks it affects the increase in tympanic temperature, heart rate and PSI, the change gap in physiological temperature on cloth masks are the highest among other masks while N95 masks affect physiological changes in facial skin temperature and heart rate. The future research need to be added more variables for the next experiment such as microclimate in masks and subjective variables such as emotions and behavior of respondents s to find out more 
physiological and subjective changes, it can be used as a basis for designing safe and comfortable masks besides physical activity. The result can be tried for physical activities that have a heavier and more varied workload.

\section{Acknowledgement}

The researcher would like to thank the research respondents, Ergonomics Laboratory assistants, supervisors and all elements and entities that support the course of this research.

\section{REFERENCES}

[1] Lee HP, Wang DY. Objective assessment of increase in breathing resistance of N95 respirators on human subjects. Ann Occup Hyg. 2011;55:917-21.

[2] Y. Tian et al., "Wearing a N95 mask increases rescuer's fatigue and decreases chest compression quality in simulated cardiopulmonary resuscitation," Am. J. Emerg. Med., no. xxxx, pp. 1-5, 2020, doi: 10.1016/j.ajem.2020.05.065.

[3] F. Pifarré, D. D. Zabala, G. Grazioli, and I. de Y. i Maura, "COVID-19 and mask in sports," Apunt. Sport. Med., vol. 55, no. 208, pp. 143-145, 2020, doi: 10.1016/j.apunsm.2020.06.002.

[4] S. Driver et al., "Effects of wearing a cloth face mask on performance, physiological and perceptual responses during a graded treadmill running exercise test," Br. J. Sports Med., pp. 1-7, 2021, doi: 10.1136/bjsports-2020-103758.

[5] D. S. Moran, A. Shitzer, and K. B. Pandolf, "A physiological strain index to evaluate heat stress," Am. J. Physiol. - Regul. Integr. Comp. Physiol., vol. 275, no. 1 44-1, 1998, doi: 10.1152/ajpregu.1998.275.1.r129.

[6] A. Frank, M. Belokopytov, Y. Shapiro, and Y. Epstein, "The cumulative heat strain index A novel approach to assess the physiological strain induced by exercise-heat stress," Eur. J. Appl. Physiol., vol. 84, no. 6, pp. 527-532, 2001, doi: 10.1007/s004210000368.

[7] G. Havenith, I. Holmér, and K. Parsons, "Personal factors in thermal comfort assessment: Clothing properties and metabolic heat production," Energy Build., vol. 34, no. 6, pp. 581591, 2002, doi: 10.1016/S0378-7788(02)00008-7.

[8] N. Ruth, L. G. Berglund, A. R. Gwosdow, and A. B. Dubois, "Thermal sensation of the body as influenced by the thermal microclimate in a face mask," Ergonomics, vol. 30, no. 12, pp. 1689-1703, 1987, doi: 10.1080/00140138708966058.

[9] Evanhoff B, Kim L, Mutha S, Jeffe D, Haase C, Andereck D, et al. Compliance with universal precautions among emergency department personnel caring for trauma patients. Ann Emerg Med 1999;33:160-5.

[10] Loeb M, Dafoe N, Mahony J, John M, Sarabia A, Glavin V, et al. Surgical mask vs N95 respirator for preventing influenza among health care workers: a randomized trial. JAMA 2009;302:1865-71.

[11] Y. C. Lin and C. P. Chen, "Thermoregulation and thermal sensation in response to wearing tight-fitting respirators and exercising in hot-and-humid indoor environment," Build. Environ., vol. 160, no. March, p. 106158, 2019, doi: 10.1016/j.buildenv.2019.05.036.

[12] R. J. Roberge, J. H. Kim, and S. Benson, "N95 filtering facepiece respirator deadspace temperature and humidity," J. Occup. Environ. Hyg., vol. 9, no. 3, pp. 166-171, 2012, doi: 10.1080/15459624.2012.660428. 
[13] A. T. Johnson, "Respirator masks protect health but impact performance: A review," J. Biol. Eng., vol. 10, no. 1, pp. 1-12, 2016, doi: 10.1186/s13036-016-0025-4.

[14] X. Zhou, Q. Ouyang, Y. Zhu, C. Feng, and X. Zhang, "Experimental study of the influence of anticipated control on human thermal sensation and thermal comfort," Indoor Air, vol. 24, no. 2, pp. 171-177, 2014, doi: 10.1111/ina.12067.

[15] D. Epstein et al., "Return to training in the COVID-19 era: The physiological effects of face masks during exercise," Scand. J. Med. Sci. Sport., 2020, doi: 10.1111/sms.13832.

[16] J. H. Kim, S. M. Benson, and R. J. Roberge, "Pulmonary and heart rate responses to wearing N95 filtering facepiece respirators," Am. J. Infect. Control, vol. 41, no. 1, pp. 24-27, 2013, doi: $10.1016 /$ j.ajic.2012.02.037.

[17] T. H. Lin, C. C. Chen, S. H. Huang, C. W. Kuo, C. Y. Lai, and W. Y. Lin, "Filter quality of electret masks in filtering 14.6-594 nm aerosol particles: Effects of five decontamination methods," PLoS One, vol. 12, no. 10, pp. 1-15, 2017, doi: 10.1371/journal.pone.0186217.

[18] J. She, H. Nakamura, K. Makino, Y. Ohyama, and H. Hashimoto, "Selection of suitable maximum-heart-rate formulas for use with Karvonen formula to calculate exercise intensity," Int. J. Autom. Comput., vol. 12, no. 1, pp. 62-69, 2015, doi: 10.1007/s11633-0140824-3.

[19] Bruce, R.A., Kusumi, F., and Hosmer, D., Maximal Oxygen Intake and Nomographic Assessment of Functional aerobic Impairment in Cardiovascular Disease, American Heart Journal, 1973,Vol. 85, pp. 546-562

[20] Y. Li H. Tokura Y.P. Guo A.S.W. Wong T. Wong J. Chung E. Newton "Effects of wearing N95 and surgical facemasks on heart rate, thermal stress and subjective sensations," Int. Arch. Occup. Environ. Health, vol. 78, no. 6, pp. 501-509, 2005, doi: 10.1007/s00420-0040584-4.

[21] Moore D, Gamage B, Bryce E, Copes R, Yassi A. BC Interdisciplinary Respiratory Protection Study Group. Protecting health care worker from SARS and other respiratory pathogens: organizational and individual factors that affect adherence to infection control guidelines.Am J Infect Control 2005;33:88-96.

[22] A. S. Baig, C. Knapp, A. E. Eagan, and L. J. Radonovich, "Health care workers' views about respirator use and features that should be included in the next generation of respirators," $\mathrm{Am}$. J. Infect. Control, vol. 38, no. 1, pp. 18-25, 2010, doi: 10.1016/j.ajic.2009.09.005.

[23] A. Scarano, F. Inchingolo, and F. Lorusso, "Facial skin temperature and discomfort when wearing protective face masks: Thermal infrared imaging evaluation and hands moving the mask," Int. J. Environ. Res. Public Health, vol. 17, no. 13, pp. 1-9, 2020, doi: 10.3390/ijerph17134624.

[24] J. H. Kim, S. M. Benson, and R. J. Roberge, "Pulmonary and heart rate responses to wearing N95 filtering facepiece respirators," Am. J. Infect. Control, vol. 41, no. 1, pp. 24-27, 2013, doi: 10.1016/j.ajic.2012.02.037.

[25] Hayashi C, Tokura H, "The effects of two kinds of masks (with/without exhaust valve) on clothing microclimates inside the mask in participants wearing protective clothing for spraying pesticides,".2004, Int Arch Occup Environ Health 77:73-78

[26] White MK, Hodous TK, Vercruyssen M, "Effects of thermal environment and chemical protective clothing on work tolerance, physiological responses, and subjective ratings," 1991,Ergonomics 34:445-457. 